\title{
SOLAIR disinfection of coliform bacteria in hand-drawn drinking water
}

\author{
V Meyer ${ }^{1 *}$ and RH Reed ${ }^{2}$ \\ ${ }^{1}$ Technikon Northern Gauteng, Department of Chemistry, Private Bag X07, Pretoria North 0116, South Africa \\ ${ }^{2}$ Division of Biomedical Sciences, Department of Chemical \& Life Sciences, University of Northumbria at Newcastle, Newcastle upon \\ Tyne, NE1 9ST, United Kingdom.
}

\begin{abstract}
SOLAIR is an alternative disinfection method utilising natural sunlight (specifically UV-A and UV-B radiation) and oxygen (from atmospheric air) to damage, inactivate and/or kill the coliform bacteria found in contaminated water. It is a natural process (virtually self-purification) with no need to add any potentially hazardous chemicals or to use sophisticated and expensive equipment.

The SOLAIR process was applied in a typical South African scenario, i.e., a rural informal village where water for domestic use is drawn from an unlined and heavily contaminated well. Results obtained showed significant reduction (99.99\%) in both the faecal and total coliform counts within 4 to $6 \mathrm{~h}$, with no subsequent reactivation of growth after $24 \mathrm{~h}$. The disinfected water complied in terms of bacteriological quality, with both the South African Bureau of Standards (SABS), drinking water standards and the South African Water Quality Guidelines (SAWQG) for domestic use as prescribed by the Department of Water Affairs and Forestry (DWAF). The rate of bacterial reduction depended on various parameters including the type and colour of plastic containers used, the initial concentration of micro-organisms in the drawn water, the irradiation levels of UV-A and UV-B rays, the oxygen concentration and distribution in the water containers, and the presence of visible turbidity.

In South Africa where more than $8 \mathrm{~m}$. people are still using water obtained directly from alternative sources such as rivers, streams, boreholes, wells, community taps and dams, SOLAIR could prove to be an efficient and an economically feasible method to be used for disinfection of hand-drawn water to an acceptable potable standard.
\end{abstract}

\section{Introduction}

Disinfection of water is an essential unit process required to destroy pathogenic micro-organisms resulting in a potable water which is safe for human consumption. Disinfected potable water reduces the occurrence of water-borne diseases and the high incidence of mortality of infants and the elderly (Genthe and Du Preez, 1995; Genthe and Seager, 1996).

However, disinfection in rural, poverty-stricken areas with no running water, remains a huge problem (Genthe and Seager, 1996). Various uncomplicated methods of disinfection have been in place for some time, but most of these methods require some form of infrastructure, economic investment and educated or informed use (Solsona, 1996). These methods include filtration, coagulation, chlorination, and oxidation. Boiling and aeration have also been used with limited application (small volumes) and with sometimes unreliable results (Solsona, 1996).

Disinfection using solar radiation (sunlight), which rendered faecal bacteria inactive by thermal radiation in high turbidity waters, has been applied for centuries (Joyce et al., 1996). A water temperature of more than $55^{\circ} \mathrm{C}$ was needed to obtain good faecal bacterial cell inactivation. Wegelin et al. (1994), Wegelin and Sommer (1996) and Sommer et al. (1997) developed the SODIS (solar water disinfection) and SOPAS (solar pasteurisation) processes which rely on the synergistic effects of solar radiation and thermal water treatment.

The advantages of using solar radiation are numerous and include: no dangerous, toxic, or hazardous by-products are produced; no smell and/or taste are imparted to the water; it is economical and

* To whom all correspondence should be addressed. 푱(012) 799 9098; fax(012) 7999022; e-mail: vermey@mweb.co.za Received 7 July 2000; accepted in revised form 11 August 2000. is easy and simple to apply. The ultraviolet (UV) component of sunlight is, however, filtered out by ozone for example, water droplets, and smoke, so that the UV light which actually reaches the earth's surface is restricted to a wavelength range of between 295 and $400 \mathrm{~nm}$. This limits the microbiocidal properties of solar radiation as a sole disinfectant.

Reed (1996 and 1997a) investigated the role of fresh air (containing oxygen and other gases in variable concentrations) in the efficiency of solar disinfection processes. The toxicity of oxygen as a disinfectant is due to the superoxide and hydroxyl radicals formed during oxidation reactions. These radicals are very reactive but short-lived, limiting their disinfection efficiency. Results recorded indicated that some faecal bacterial species have a resistance to radiation inactivation in the absence of oxygen. The research led to the development of a process called solar photooxidative disinfection or SOLAIR.

SOLAIR combines the use of solar (UV) radiation and oxygen from the natural environment in an alternative disinfection method with a higher microbiocidal efficiency than the two disinfectants separately (Reed, 1996 and 1997a,b,c). This method is, in effect, a natural process (self-purification) without the addition of any potentially hazardous chemicals or a need for sophisticated and/or expensive equipment.

The following represents results from a full-scale field application of the SOLAIR disinfection method on hand-drawn drinking water in a typical rural and poverty-stricken scenario.

\section{Materials and methods}

\section{Source of hand-drawn water}

Water was abstracted from an unprotected well in the Bridgeview Mandela Village near Hammanskraal, Pretoria. The water from the 
well was hand-drawn using buckets and then transferred to the plastic water storage containers for general domestic use. As the well is not protected or properly lined, it is contaminated by animal, bird and human faeces, polluted soil, polluted groundwater and by the users abstracting water every day.

\section{Experimental set-up}

Water was collected from the well into 25 I white/opaque plastic containers which is representative of the containers used by the local community members. The plastic containers were filled with $20 \mathrm{I}$ of the collected water, closed, shaken vigorously for $5 \mathrm{~min}$, and placed in direct sunlight for the duration of the experiment. The containers were shaken every hour after sampling to ensure that the oxygen which diffuses through the plastic, is dispersed evenly throughout the water mass.

Two controls were set up. Control A was deoxygenated by bubbling nitrogen through it and placed in direct sunlight. Control $\mathrm{B}$ was placed inside the house of one of the villagers, protecting it from direct solar radiation. Both controls were also shaken every hour directly after sampling the water for microbiological and physical analyses.

\section{Physical analyses}

The following physical analyses were performed hourly before shaking of the containers, using a calibrated Mettler Toledo portable meter (M90) with temperature compensation as a standard feature on all probes:

- temperature $\left(-0.5^{\circ} \mathrm{C}\right.$ to $100^{\circ} \mathrm{C}$, resolution $\left.0.1^{\circ} \mathrm{C}\right)$

- dissolved oxygen (DO) (1 to $10 \mathrm{mg} / \mathrm{l}$, resolution $0.1 \mathrm{mg} / \mathrm{l}$ )

- total dissolved solids (TDS) (1 000 to $10000 \mathrm{mg} / \mathrm{l}$, resolution $100 \mathrm{mg} / \mathrm{l})$

- $\mathrm{pH}(0$ to $14 \mathrm{pH}$ units, resolution $0.01 \mathrm{pH}$ units)

Turbidity was measured with a portable Lovibond (DRT 15CE) turbidity meter. It was standardised and calibrated with a $0.02 \mathrm{NTU}$ reference solution and measured 0 to $1000 \mathrm{NTU}(+/-4 \%)$.

The UV-A and UV-B irradiances were measured with a Delta Ohm microprocessor controlled quantum photo/radiometer (HD 9021). The UV-A probe measured from 10 nanowatt $/ \mathrm{cm}^{2}$ to 200 $\mathrm{mW} / \mathrm{cm}^{2}( \pm 4 \%)$ in the spectral range 315 to $400 \mathrm{~nm}$, peaking at 365 $\mathrm{nm}$. The UV-B probe measured from $10 \mathrm{nW} / \mathrm{cm}^{2}$ to $200 \mathrm{~mW} / \mathrm{cm}^{2}$ $( \pm 4 \%)$ in the spectral range of 280 to $315 \mathrm{~nm}$, peaking at $312 \mathrm{~nm}$.

\section{Microbiological analyses}

Total coliform (TC) and faecal coliform (FC) analyses were performed hourly during the experimental period and again $24 \mathrm{~h}$ after the last sample had been taken. The standard membrane filter (MF) technique was used. As suggested (SABS, 1984 and Millipore, 1992), $100 \mathrm{ml}$ water sample volumes were filtered for both TC and FC analyses.

The chosen sample volume was filtered through $47 \mathrm{~mm}$ membranes of $0.45 \mu \mathrm{m}$ (HA-type, Millipore) and $0.7 \mu \mathrm{m}$ (HC-type, Millipore) pore sizes, respectively. The HC-type $0.7 \mu \mathrm{m}$ filter membrane was chosen, because this type of membrane allows for the recovery of stressed faecal coliforms, giving a more reliable
TABLE 1

verage results of physical analyses of water samples (Experiment, Control A and Control B)

\begin{tabular}{|c|c|c|c|c|c|}
\hline & \multirow{2}{*}{$\begin{array}{c}\text { Temperature } \\
\left({ }^{\circ} \mathbf{C}\right)\end{array}$} & \multicolumn{2}{|c|}{ DO (mg/l) } & \multirow{2}{*}{$\begin{array}{c}\text { TDS } \\
(\mathbf{g} / \mathbf{l})\end{array}$} & $\begin{array}{c}\text { Turbidity } \\
(\mathbf{N T U})\end{array}$ \\
\cline { 3 - 4 } & $\begin{array}{c}\text { Experiment } \\
\text { and Control B }\end{array}$ & Control A & & \\
\hline 5 & 16 & 2.1 & 0 & 2.1 & 2.1 \\
65 & 16.8 & 2.3 & 0.1 & 2.3 & 2 \\
6 & 17.5 & 2.5 & 0.2 & 2.2 & 2.05 \\
6 & 18.2 & 2.1 & 0.1 & 2.3 & 2.11 \\
6 & 19 & 2 & 0.3 & 2.4 & 2.1 \\
5 & 19.1 & 1.9 & 0.1 & 2.3 & 2.2 \\
7 & 18.4 & 2.1 & 0.1 & 2.2 & 2.12 \\
\hline & 18 & 2 & 0.1 & 2.3 & 2 \\
\hline
\end{tabular}

analytical result.

The $0.45 \mu \mathrm{m}$ pore membrane filters were transferred aseptically to $65 \mathrm{~mm}$ petri dishes containing M-Endo agar (Merck). The inverted petri dishes were incubated for $24 \mathrm{~h}$ at $35^{\circ} \mathrm{C}\left( \pm 5^{\circ} \mathrm{C}\right)$. The $0.7 \mu \mathrm{m}$ membrane filters were transferred to petri dishes containing $\mathrm{M}-\mathrm{FC}$ agar (Merck) and incubated invertedly at $44.5^{\circ} \mathrm{C}\left( \pm 0.2^{\circ} \mathrm{C}\right)$ for $24 \mathrm{~h}$.

Colonies with a gold metallic-green sheen on the M-Endo agar were considered to be positive for TC growth and, light- to darkblue colonies on the M-FC agar as positive for FC growth. All results were reported as $\log \mathrm{CFU}$ (coliform units)/100 ml.

\section{Results and discussion}

\section{Physical analyses}

Table 1 summarises the results of the physical analyses performed on the water samples taken every hour from the experimental setup. It indicates clearly that the SOLAIR process does not have any significant effect on the physical characteristics of the water, because all parameters remained nearly constant over the experimental period. From the data presented in Table 1, it can be seen that temperature does not play a role in the destruction of the $\mathrm{TC}$ and FC organisms in the contaminated water as it remains low at around $18^{\circ} \mathrm{C}$, even with mid-day atmospheric temperatures in excess of $34^{\circ} \mathrm{C}$. This indicates that the UV irradiance and the oxygen diffusing from the atmospheric air, are the only two factors that play a role in the destruction/inactivation of coliform bacteria in the SOLAIR disinfection method.

The DO in the water container ranged between 1.9 and 2.5 $\mathrm{mg} / \mathrm{l}$. Oxygen is usually used by bacterial cells for energy-yielding chemical reactions and not for bacterial growth. The toxicity to some species of bacteria (including members of the Enterobacteriaceae) is due to superoxide radicals, hydroxyl radical and hydrogen peroxide which are produced during oxidation reactions. All of these molecules can damage the DNA of the bacterial cell. However, some bacteria have developed a protective mechanism in which the enzyme superoxide dismutase is produced. This enzyme converts the superoxide radicals rapidly to hydrogen peroxide, which in turn is dissipated by catalase and peroxidase to water and oxygen. The enzymes are produced through information from the DNA. Thus, if the DNA is damaged/inactivated by UV irradiation, for example, this protective mechanism will be inactivated (Pelczar et al., 1993). 


\section{UV-A and UV-B irradiance levels}

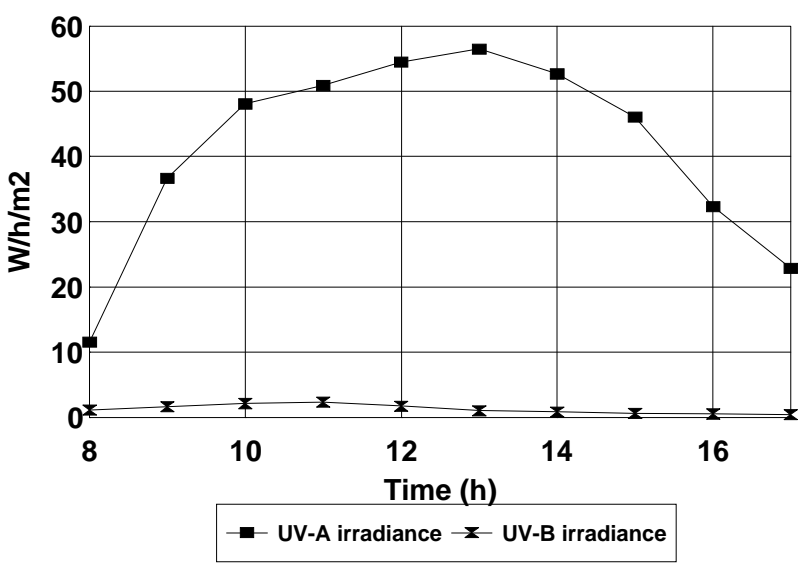

Figure 1

$U V-A$ and $U V-B$ irradiance levels over the experimental period

Total coliform (TC)

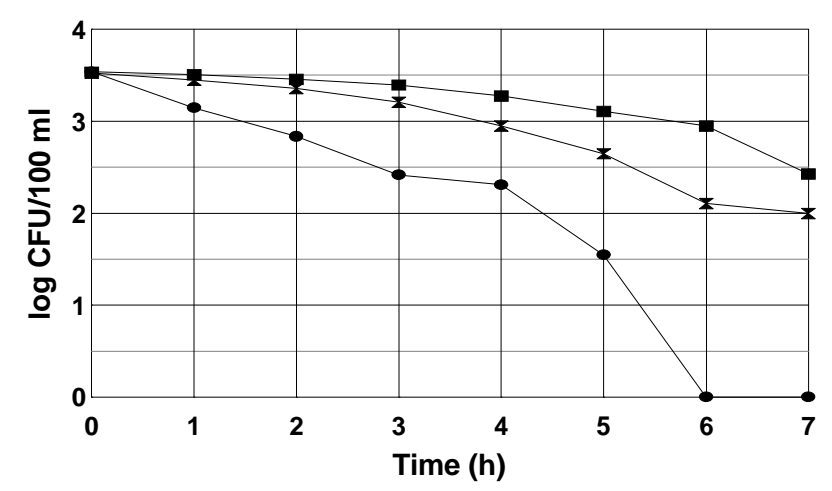

- Experiment - UV and air $\mathbf{Z}-$ Control A - UV only $\rightarrow$ Control B - air only

Figure 2

Total coliform concentration over experimental period

Faecal coliform (FC)

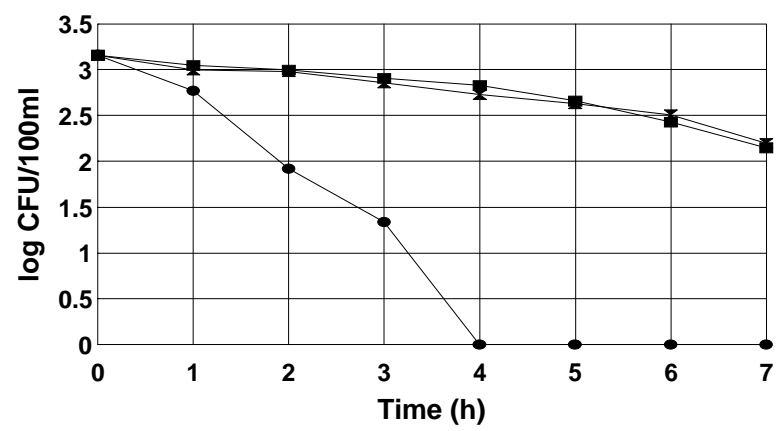

- Experiment - UV and air $\leq$ Control A - UV only $\rightarrow-$ Control B - air only

Figure 3

Faecal coliform concentrations over the experimental period
The measured UV irradiance levels are illustrated in Fig 1. As expected, the UV-A irradiance is much higher than the UV-B irradiance, because most of the lower wavelength UV components from the sunlight are filtered by ozone, water droplets, and smoke. The UV light which actually reaches the earth's surface is restricted to a wavelength range of 295 to $400 \mathrm{~nm}$. This, in effect, limits the microbiocidal properties of solar UV light as a disinfectant, as the highest bactericidal action will occur at $260 \mathrm{~nm}$, i.e. the wavelength at which the DNA of a bacterial cell absorbs the most UV light.

SOLAIR disinfection overcame both these limitations by applying solar radiation in the presence of oxygen in concentrations of more than $2 \mathrm{mg} / \mathrm{l}$. This combined effect on bacterial cells can be seen in the results of the microbiological analyses as illustrated in Figs. 2 and 3.

\section{Microbiological analyses}

Figure 2 shows that $100 \%$ inactivation/destruction of total coliforms (TC) was obtained within a period of $6 \mathrm{~h}$ during the application of SOLAIR disinfection to the hand-drawn water. Control A showed a $40 \%$ reduction over the same period and only a $43 \%$ reduction in cell concentration over the total experimental period of $7 \mathrm{~h}$. Control $\mathrm{B}$ had a $17 \%$ reduction after $6 \mathrm{~h}$ and $31 \%$ after completion of the experiment.

Figure 3 illustrates the faecal coliform (FC) inactivation/ destruction. Within a period of $4 \mathrm{~h}$ destruction of $\mathrm{FC}$ was $100 \%$ effective, while Control A showed a $14 \%$ reduction and Control B a $10 \%$ reduction in FC concentration after the same period. Controls A and B had final reductions in cell concentrations of $30 \%$ and $32 \%$ respectively after completion of the experimental period.

After a $24 \mathrm{~h}$ lag period, the SOLAIR disinfected water showed no growth on the respective inoculated agar plates. This indicates that the bacterial cells were irreversibly damaged or killed by the said disinfection process. However, increased concentrations of both TC and FC were observed in both controls after the $24 \mathrm{~h}$ lag period.

From the data presented above, it can be seen that the disinfection efficiency of the SOLAIR process is higher than the process of using solar UV radiation (Control A) or oxygen (Control B) separately. The disinfected water complied with the potable drinking water standards and guidelines in terms of bacteriological quality as laid down by the SABS (1984) and DWAF (1996a \& b), respectively. This will have a major impact on the reduction of incidences of diseases related to poor microbiological water quality.

A major disadvantage of the suggested method, is that no residual disinfection power will be found in the water after treatment with SOLAIR. This makes it very difficult to guarantee that the water is safe from any secondary contamination. Secondary contamination can, however, be limited or prevented, by practising good hygiene in the respective households.

\section{Conclusions}

Based on the results of all the field trials, the following conclusions can be drawn:

- SOLAIR is applicable and effective in small volumes of handdrawn water (2 to $25 \mathrm{I}$ ).

- Intermittent vigorous shaking is important during the disinfection period, in order to dissolve and disperse the diffused and DO throughout the volume of water and to ensure contact of all organisms in the water with the absorbed UV light. 
- Visible turbidity should be removed before the SOLAIR disinfection process can be applied, because turbidity will interfere with the disinfection efficiency.

- The containers must be kept closed with a lid and must be exposed to full/direct sunlight at all times.

- A minimum of $4 \mathrm{~h}$ is required for effective coliform disinfection, i.e., compliance with the SABS (1984) drinking water standards and the DWAF Water Quality Guidelines (1996a \& b) for TC and/or FC. This will depend on the initial concentration of micro-organisms, the DO concentration, the UV concentration and the type and colour of plastic container that is used. It was found with further studies that cloud cover did not limit the UV radiation significantly.

- It is emphasised that no residual disinfection power is available after SOLAIR disinfection of the hand-drawn water. Education of the end users is thus imperative for the successful application of the SOLAIR disinfection process, as good hygienic practices will prevent or minimise secondary contamination of the SOLAIR disinfected water.

\section{Acknowledgements}

The Water Research Commission (WRC) and the Directorate of Research, Technikon Northern Gauteng funded the project entitled "Alternative disinfection treatment method of faecal contaminated drinking water: The feasibility and applicability of the SOLAIR process in the South African scenario." The fieldwork was performed with the help of senior students enrolled for the National Diploma: Water Care at theTechnikon Northern Gauteng, Soshanguve, Pretoria.

The authors wish to thank Ms AM Nel for editorial support.

\section{References}

DWAF (1996a) South African Water Quality Guidelines. Vol 1: Domestic Water Use. Department of Water Affairs and Forestry, Pretoria.

DWAF (1996b) A Guide for the Health Related Assessment of the Quality of Water Supplies. Department of Water Affairs and Forestry and Department of Health, Pretoria.

GENTHE B and DU PREEZ M (1995) Evaluation of Rapid Methods for the Detection of Indicator Organisms in Drinking Water. WRC Report No $610 / 1 / 95$.

GENTHE B and SEAGER J (1996) The Effects of Water Supply, Handling and Usage on Water Quality in Relation to Health Indices in Developing Communities. WRC Report 562/1/96.

JOYCE TM, McGUIGAN KG, ELMOORE-MEEGAN M and CONROY RM (1996) Inactivation offaecal bacteria in drinking water by solar heating. Appl. Environ. Microbiol. 62 (2) 399-402.

MILLIPORE(1992) Water Microbiology. Laboratory and Field procedures.

PELCZAR MJ, CHANECS and KRIEGNR(1993) Microbiology. Concepts and Applications. McGraw-Hill.

REED RH (1996) Sol-air water treatment. 22 ${ }^{\text {nd }}$ WEDC Conf. Proc., New Dehli, India.

REED RH (1997a) Solar inactivation of faecal bacteria in water: The critical role of oxygen. Lett. Appl. Microbiol. 24 276-280.

REED R (1997b) Sunshine and fresh air: A practical approach to combating water-borne disease. Waterlines 15 (4) 27-29.

REED RH (1997c) Innovations in solar water treatment. $23^{\text {rd }}$ WEDC Conf.Proc., Durban, South Africa.

SOMMER B, MARINO A, SOLARTE Y, SALAS ML, DIEROLF C, VALIENTE C, MORA D, RECHSTEINER R, SETTER P, WIROJANAGUD W, AJARMEH H, AL-HASSEN A and WEGELIN M (1997) SODIS - An emerging water treatment process. J.Water SRT Aqua 46 (3) 127 - 137.

SABS (1984) South African Standard: Specification for Waterfor Domestic Supplies. SABS 241.

SOLSONAF (1996) Disinfection for Small Water Supplies. CSIR Technical Guide No C 2878.

WEGELIN M, CANONICA S, MESCHNER K, FLEISCHMANN T, PESARO F and METZLER (1994) Solar water disinfection: Scope of the process and analysis of radiation experiments. J.Water SRT - Aqua 43 (3) 154 - 169.

WEGELIN M and SOMMER B (1996) Demonstration projects on solar water disinfection. SANDEC News (2) 11-13. 